Short Communication

\title{
First report on the prevalence of Klossiella muris in Mus musculus for S. Miguel Island - Azores (Portugal)
}

\author{
R. Camarinho ${ }^{a, b, *}$, P.V. Garcia ${ }^{a, c}$, A.C. Mendonça ${ }^{a}$, A.S. Rodrigues ${ }^{a, b}$ \\ ${ }^{a}$ Faculty of Sciences and Technology, University of the Azores, 9501-801 Ponta Delgada, Portugal \\ ${ }^{\mathrm{b}}$ IVAR - Instituto de Vulcanologia e Avaliação de Riscos, University of the Azores, 9501-801 Ponta Delgada, Portugal \\ ${ }^{\mathrm{c}}$ CE3C - cE3c, Centre for Ecology, Evolution and Environmental Changes/Azorean Biodiversity Group, University of the Azores, $9501-801$ Ponta Delgada, Azores, \\ Portugal
}

\section{A R T I C L E I N F O}

\section{Keywords:}

Klossiella muris

Coccidian protozoa

House mouse

Kidney inflammation

\begin{abstract}
A B S T R A C T
Klossiella is a genus of apicomplexan coccidian parasites with a global distribution, whose members typically infect the renal tissue of a wide variety of vertebrate hosts with a high level of host specificity. The presence of this parasite has been previously associated with kidney inflammatory processes. To our knowledge, this is the first report on the prevalence of Klossiella muris in the house mouse (Mus musculus) in Portugal (São Miguel Island - Azores). The prevalence of $K$. muris was determined through histopathological examination of renal tissue collected during necropsy of 130 mice captured between the years of 2011-2019. K. muris was diagnosed in $45.38 \%$ ( $\left.{ }_{95}: 40.9-85.4\right)$ of the examined mice. Infection with this parasite was associated with mild to severe kidney inflammation, assessed by the presence of inflammatory processes in the renal cortex and medulla. Capsule: First record on coccidiosis caused by infection of Klossiella muris in Mus musculus in Portugal.
\end{abstract}

\section{Introduction}

Klossiella sp. (apicomplexam: Klossiellidae) is an apicocomplexan parasite that parasitizes vertebrates and usually infects the kidneys (Bennet et al., 2007). Klossiella parasites exhibit considerable host specificity (Yang and Grice, 1964) and have been found in a wide variety of animals [(Klossiella cobayae - guinea pigs; Klossiella killichi - bats (Taylor et al., 1979); Klossiella quimrensis and Klossiella dulcis - bandicoots (Bennet et al., 2007; Ardiaca et al., 2016); Klossiela equi - zebras (Suedmeyer et al., 2006); Klossiella sp.- spiny mouse (Meshorer, 1970)]; Klossiella muris - house mouse (Smith and Johnson, 1889; Elmadawy and Radwan, 2011) in both wild and laboratory conditions.

Infections by this parasite, have been reported in several countries such as: Peru (Rosenmann and Morrison, 1975), Iran (Wilson and Edrissian, 1974), Egypt (Elmadawy and Radwan, 2011), Australia (Bennet et al., 2007), Israel (Meshorer, 1970) among others. Renal coccidiosis in mice was first reported in 1889 by Smith and Johnson (1889). Although initially the Klossiella infection was considered a neglectable pathology, the reports of renal coccidiosis worldwide spread arose the question of the non-pathologic status (Taylor et al., 1979). Studies on Klossiella reported histological changes that could potentially impair kidney metabolism under stress conditions (Rosenmann and Morrison, 1975) such as interstitial nephritis (Ardiaca et al., 2016). The infection occurs through ingestion of sporocysts in contaminated food or water. The parasite is ingested and within the gut sporozoites escape from the sporocyst and invade the blood stream. Upon reaching the kidney, within the epithelium of the kidney the sporozoite undergoes merogony followed by gametogony and sporogony. It then produces polysporocystic oocysts without a resistant oocyst wall. The resistant sporocysts are then released into the lumen of the renal tubules, and from there they pass to the bladder and thus into the environment (Taylor et al., 1979; Yang and Grice, 1964). Although extrarenal infections can occur (Chavrakov, 1974; Zwart, 1964), parasites are usually found in the epithelial cells of renal tubules, glomeruli, lumen of the convoluted tubules and endothelium (Yang and Grice, 1964).

There is no treatment available for Klossiella sp. infection. At this moment, prevention and control rely on proper hygiene measures to reduce environmental contamination (Taylor et al., 1979).

To our knowledge, to date, no surveys on $K$. muris infection in Mus musculus have been carried out in Portugal, and so, the prevalence of renal coccidiosis in wild mice remains unknown. In this study we aimed to: i) confirm the occurrence in Portugal of $K$. muris infections in wild

\footnotetext{
* Corresponding author at: Faculdade de Ciências e Tecnologia, Universidade dos Açores, Rua da Mãe de Deus, Apartado 1422, 9501-801 Ponta Delgada, Açores, Portugal.

E-mail addresses: Ricardo.AD.Camarinho@uac.pt (R. Camarinho), Patricia.V.Garcia@uac.pt (P.V. Garcia), Armindo.S.Rodrigues@uac.pt (A.S. Rodrigues).
} 


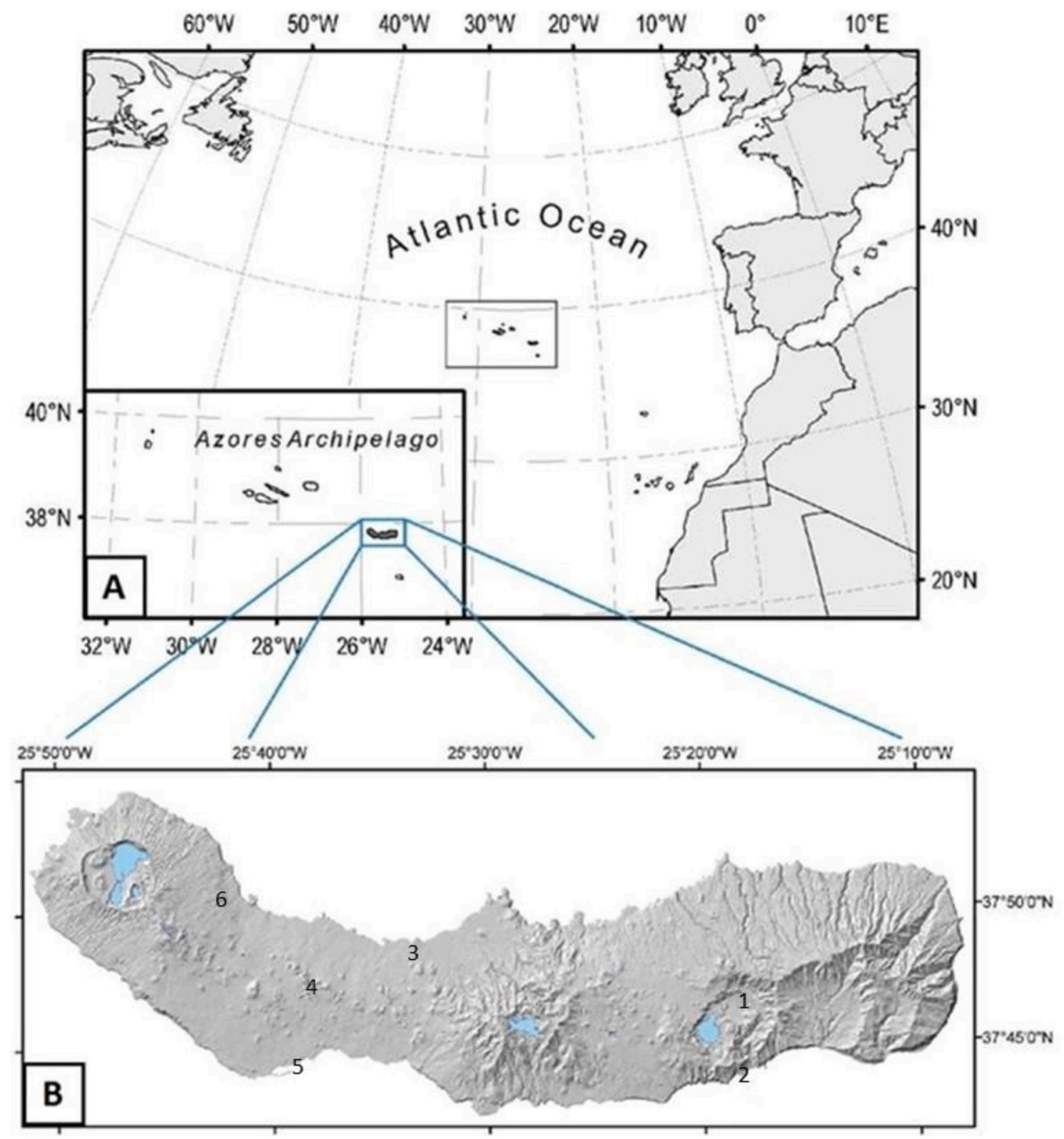

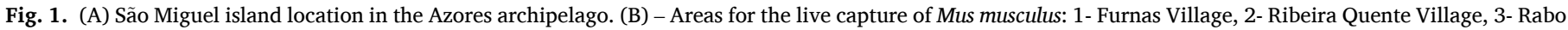
de Peixe Village, 4- Pinhal da Paz, 5- São Roque, 6- Santo António.

Mus musculus; ii) assess the prevalence of renal coccidiosis in S. Miguel Island; and, iii) evaluate the association between the level of parasitic infection and the occurrence of renal pathological lesions.

\section{Material and methods}

A total of 130 mice were captured in S. Miguel Island (Fig. 1A). Mice were screened for $K$. muris in kidney histological sections. Mice live catch-traps were placed in the following locations (Fig. 1B): 1 - Furnas Village - a rural location with 1500 habitants, located in the volcanic complex of Furnas Volcano; 2 - Ribeira Quente - another rural location, located in the volcanic complex of Furnas Volcano, but with 800 habitants; 3 - Rabo de Peixe - a rural location with 9000 habitants, located in the north coast of the island; 4 - Pinhal da Paz - a recreational green area of Ponta Delgada city; 5 - São Roque - a urbanized area in the periphery of Ponta Delgada city; 6 - Santo António - a rural location with 1800 habitants, located in the northwestern part of S. Miguel.

Animals were euthanized with isofluorane, ensuring a painless death. The following data was collected: body weight, sex and age. The age of each mouse was determined based on dry crystalline lens mass as described by Quéré and Vincent (1989). After the euthanasia, both kidneys were surgically removed, fixed in $4 \%$ formaldehyde and processed for routine histology.

The study was approved by the Ethics Committee of the University of Azores (Ref.10/2020). All the experimental procedures were carried out according to the European Convention for the Protection of Vertebrate Animals used for Experimental and Other Scientific Purposes (ETS 123), European directive 2010/63/EU and Portuguese Law Decree (DL 113/ 2013).

For each mouse, one slide with a series of $4 \mu \mathrm{m}$ thickness sections of both kidneys was prepared and stained with Hematoxylin \& Eosin in the standard manner (Martoja et al., 1970).

$K$. muris diagnosis was based on the presence of parasite oocysts in transversal histological sections of the kidneys. Morphological identification of oocysts was performed according to Yang and Grice (1964). Inflammatory status was assessed and scored from 0 to 3 , modified from 


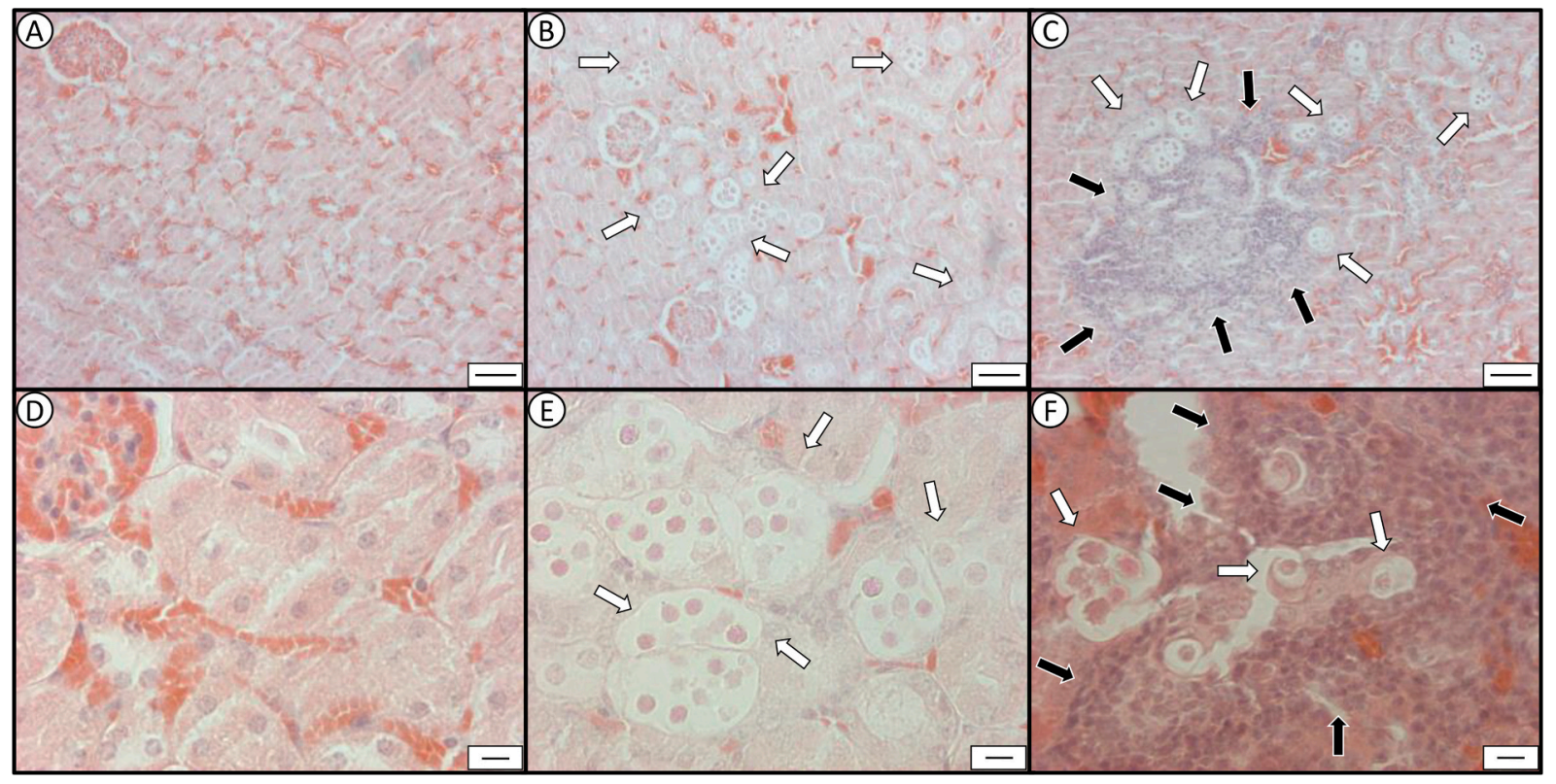

Fig. 2. Kidney cortex histology stained with Hematoxylin \& Eosin. (A) and (D) -Healthy kidney histology; (B) and (E) -Kidney histology of mice with Klossiella muris presence (White arrows) in various stages; (C) and (F) - Kidney inflammatory status (Black arrows). (A), (B) and (C) scale bar $=50 \mu \mathrm{m}$; (D), (E) and (F) scale bar = $10 \mu \mathrm{m}$.

Keil et al., 2009, (0 - absent; 1 - presence of inflammatory cells, 2 increased presence of inflammatory cells, glomerular inflammation, one or two areas, 3- more than 2 areas with clustered inflammatory cells, glomerular inflammation). The $\mathrm{CI}_{95}$ was calculated the population proportion. Chi-square test was performed to analyze the association between Klossiella sp. infection and kidney inflammatory status. Spearman's rank correlation test was performed to analyze the correlation between Klossiella sp. infection and kidney inflammatory status, gender and age using SPSS - Statistical Package for Social Sciences version 24.0 (SPSS Inc., Chicago, USA). A $P$ value of less than 0.05 was considered significant.

\section{Results}

The sex-ratio of Mus musculus used in this study was $\approx 50 \%$ (71 males and 59 females). In average, mice weighted $14.43 \pm 2.56 \mathrm{~g}$., and were $178 \pm 84$ days old. A total of 59 mice were infected with $K$. muris. The prevalence of infection was 45.38\% [CI 95 : 49.3-68.0 (59 of 130 mice)] for São Miguel Island. For each locality, we registered the following prevalence: Furnas $-63.16 \%$ [ $\mathrm{CI}_{95}: 40.9-85.4$ (12 of 19 mice)], Ribeira Quente - 17.65\% [ $\mathrm{CI}_{95}:-0.01-0.36$ (3 of 17 mice)], Rabo de Peixe 68.97\% [ [CI $95: 51.8-86.1$ (20 of 29 mice)], Pinhal da Paz - 46.15\% [CI ${ }_{95}$ : 26.6-65.7 (12 of 26 mice)], São Roque - 41.18\% [CI ${ }_{95}: 17.1-65.3$ (7 of 17 mice)], Santo António - 22.72\% [ $\mathrm{CI}_{95}: 4.8-40.7$ (5 of 22 mice)]. Inflammation in the kidneys was observed in $35.38 \%$ of the captured mice ( 46 of 130 ). From these, $52.17 \%$ of the mice ( 24 of 46 ) presented a high inflammatory status (score 2 or 3). K. muris infection was associated with kidney inflammatory status $\left(\mathrm{X}^{2}=67.8 ; P<0.01\right)$. K. muris infection correlated positively with mice age $\left(\mathrm{r}_{\mathrm{s}}=0.514 ; P<0.01\right)$. No correlation was found between $K$. muris infection and gender. K. muris infection was significantly and positively correlated with the kidney inflammatory status $\left(\mathrm{r}_{\mathrm{s}}=0.657 ; P<0.01\right)$.

\section{Histopathological findings}

K. muris oocysts were more abundant in the kidney cortex (Fig. 2B), but were also found in the kidney tubules, glomeruli and lumen of the convoluted tubules. Mice with high inflammatory status (score 2 or 3 ) $(52.17 \%)$ presented loss of parenchymal architecture due to the inflammatory status and subsequent lesions on the multifocal parasite clusters (Fig. 2C). No necrosis, congestion of the blood vessels or pyknosis of the nucleus was found in the kidneys, however, some granulomas containing debris of the parasite oocysts presented intense granulomatous inflammatory infiltrate (Fig. 2C).

\section{Discussion}

To our knowledge this is the first report of $K$. muris infection in mice in Portugal. Our results show that a high prevalence of $K$. muris can be found in the house mouse Mus musculus, especially in the captured areas of Furnas Village, Rabo de Peixe and Pinhal da Paz. The higher prevalence can be due to the geographic properties of the terrain, where rain patterns and temperature differences can affect the life cycle of the parasite. The year-round high humidity and mild temperature of Azorean climate (Portugal) could offer better conditions for the survival of the parasite in the environment, and thus contribute to higher transmission rates, explaining the high prevalence observed in all populations analyzed in this study.

The prevalence of $K$. muris has previously been determined as $28.18 \%$ in laboratory mice (Swiss albino mice) and $37.14 \%$ in wild mice (Mus musculus) (Elmadawy and Radwan, 2011). According to the former study conducted in Egypt, the low prevalence of infection in laboratory mice may result from better housing conditions compared to wild populations. In fact, transmission of the parasite tends to diminish when hygiene is improved.

The absence of kidney malfunctions in $K$. muris infected mice observed in this study is in line with previous reports (Wilson and Edrissian, 1974; Elmadawy and Radwan, 2011). Moreover, we found that the infected mice can have mild to severe inflammations, without evidence of kidney failure or necrosis. Contrarily to the first studies, where this coccidiosis was considered a neglectable pathology, Stojanov and Dvetanov (1965) observed that massive parasite infections caused necrosis of the epithelial lining of the kidney tubules, resulting in functional disturbance of the kidneys and death in guinea pigs. Later, Hofman and Hanichen (1970) referred that coccidiosis caused by Klossiella sp. infection produces significant pathological changes in the mice kidneys, and Rosenmann and Morrison (1975) emphasized that this parasite can impair kidney metabolism, specially under stress 
conditions.

At this moment, no available diagnosis ante-mortem is reliable (Bennett et al., 2007). Although the sporocysts of this coccidiosis can be detected in the urine by traditional concentrations methods followed by microscopic examination, this type of analysis has been shown to be insensitive for the diagnosis of this parasite (Reppas and Collins, 1995). Histological analysis of multiple sections of kidney still remains the gold standard to a definitive diagnosis of K. muris (Taylor et al., 1979; Elmadawy and Radwan, 2011).

This study also highlights the possibility that other species of mice present in the Azorean archipelago can be infected. Thus, a broader survey should be conducted, not only within São Miguel Island, but also extended to remaining islands of the archipelago and Portugal mainland.

\section{Declaration of competing interest}

The authors declare that there are no conflicts of interest.

\section{Acknowledgments}

The authors would like to thank Paulo Melo for the field assistance in the capture of Mus musculus. Ricardo Camarinho is currently supported by a PhD fellowship grant (M3.1.a/F/048/2015) from Fundo Regional da Ciência (Regional Government of the Azores).

\section{Ethical statement}

All the experimental procedures were carried out according to the European Convention for the Protection of Vertebrate Animals used for Experimental and Other Scientific Purposes (ETS 123), European directive 2010/63/EU and Portuguese Law Decree (DL 113/2013).

\section{References}

Ardiaca, M., Bennet, M.D., Montesinos, A., Juan-Sallés, C., Dipl, A.C.V..P., SorianoNavarro, M., 2016. Klossiella dulcis N. sp. (apicomplexa: Klossiellidae) in the kidneys of Petaurus breviceps (marsupialia: petauridae). J. Zoo Wildl. Med. 47 (2), 622-627.

Bennet, M.D., Woolford, A.J., O'Hara, P.K., Nicholls, K.S., Warren, S.J. Friend, Swan, R. A., 2007. Klossiella quimrensis (apicomplexa: klossiellidae) causes renal coccidiosis in western barred bandicoots Perameles bougainville (marsupialia: peramelidae) in Western Australia. J. Parasitol. 93 (1), 89-92.

Chavrakov, G., 1974. Localization of Klossiella muris in various organs of white Wistar rats. Eksp. Med. Morfol. 13 (1), 59-62.

Elmadawy, R.S., Radwan, M.E.I., 2011. Klossiella muris infecting laboratory and wild mice in Egypt. Global Vet. 6, 281-285.

Hofman, V.H., Hanichen, T., 1970. Klossiella cobayae - Nierenkokzidiose bei Meerschweinchen. Berl. Munch. Tierartztl. Wochensch. 83, 151-153.

Keil, D.E., Peden-Adams, M.M., Wallace, S., Ruiz, P., Gilkeson, G.S., 2009. Assessment of trichloroethylene (TCE) exposure in murine strains genetically-prone and non-prone to develop autoimmune disease. J. Environ. Sci. Health A 44, 443-453.

Martoja, R., Martoja-Pierson, M., Grumbles, L.C., Moncanut, M.E., Coll, M.D., 1970. Técnicas de histologia animal, First ed. Toray-Masson, Barcelona.

Meshorer, A., 1970. Interstitial nephritis in the spiny mouse (Acomys cahirinus) associated with Klossiella sp. infection. Lab. Anim. 4 (2), 227-232.

Quéré, J.P., Vincent, J.P., 1989. Détermination de l'âge chez le mulot gris (Apodemus sylvaticus L., 1758) par la pesée des cristallins. Mammalia 53, 287-294. https://doi. org/10.1515/mamm.1989.53.2.287.

Reppas, G.P., Collins, G.H., 1995. Klossiella equi infection in horses; sporocyst stage identified in urine. Aust. Vet. J. 72 (8), 316-318.

Rosenmann, M., Morrison, P.R., 1975. Impairment of metabolic capability in feral house mice by Klossiella muris infection. Lab. Anim. Sci. 25 (1), 62-64.

Smith, T.M.D., Johnson, P.H., 1889. On coccidium (Klossiella muris, gen. et spec. nov.) parasitic in the renal epithelium of the mouse. J. Comp. Med. Surg. x pp.:211.

Stojanov, D.P., Dvetanov, J., 1965. Uber die Klossiellose bei Meerschweinchen. Z. Parasitendk. 25, 350-358.

Suedmeyer, W.K., Restis, E., Beerntsen, B.T., 2006. Klossiella equi infection in a Hartmann's mountain zebra (Equus zebra hartmannae). J. Zoo Wildl. Med. 37 (3), $420-423$.

Taylor, J.L., Wagner, J.E., Kusewitt, D.F., Mann, P.C., 1979. Klossiella parasites of animals: a literature review. Vet. Parasitol. 5, 137-144.

Wilson, V.C.L.C., Edrissian, G.H., 1974. An infection of Klossiella muris cited in Smith and Johnson, 1902, in a wild Mus musculus from Iran. Trans. R. Soc. Trop. Med. Hyg. 68 (1), 8 .

Yang, Y.H., Grice, H.C., 1964. Klossiella muris parasitism in laboratory mice. Can. J. Comp. Med. Vet. Sci. 28 (3), 63-66.

Zwart, P., 1964. Intraepethelial protozoon, Klossiella boae n. sp. in the kidneys of a Boa constrictor. J. Protozool. 11, 261-263. 